\title{
Comparison of the isotope dilution method for determination of the ileal endogenous amino acid losses with labelled diet and labelled pigs*
}

\author{
Vincent Hess, Philippe Ganier, Jean-Noel Thibault and Bernard Sève $\dagger$ \\ INRA, Station de Recherches Porcines, 35590 Saint Gilles, France
}

(Received 22 September 1998 - Revised 18 June 1999 - Accepted 9 August 1999)

\begin{abstract}
The aims of the present study were first to compare the amino acid dilution method performed using labelled animals with that using labelled diets, and second to determine real digestibilities and total ileal endogenous losses of $\mathrm{N}$ and amino acids. Two diets containing pea cultivars (Solara and Amino) and a protein-free diet were compared in a $3 \times 3$ Latin-square experiment. The three pigs were each prepared with an ileo-rectal anastomosis and were continuously infused with $\left[1-{ }^{13} \mathrm{C}\right]$ leucine. For each cultivar, ${ }^{15} \mathrm{~N}$-labelled and unlabelled diets were formulated. The real digestibility and endogenous losses of leucine were higher when obtained by labelling the pig than by labelling the foodstuff. This was due either to the inadequate estimation of the endogenous protein enrichment in the first case or to the importance of dietary $\mathrm{N}$ recycling in the second case. However, in both cases the ileal endogenous losses of $\mathrm{N}$ and amino acids were higher than the basal losses determined with the protein-free diet. There were significant differences between the two pea cultivars in terms of phenylalanine and leucine when measured with labelled diets. It is suggested that, although ileal endogenous losses may be underestimated, using labelled feedstuffs is of great interest due to the direct estimation of the individual amounts of amino acids.
\end{abstract}

Amino acids: Isotope dilution method: Endogenous losses

The determination of the real digestibilities of $\mathrm{N}$ and amino acids (AA) in feedstuffs is of great interest in the context of pig production because it allows better adjustment of the supplies to the requirement and reduction of $\mathrm{N}$ pollution. One of the most commonly used techniques to determine real digestibility and total endogenous ileal losses is the isotope dilution method (Souffrant et al. 1981). The isotope dilution method can be performed either with labelled diets or with labelled animals. Fast recycling of dietary AA in the endogenous secretions impairs the results obtained with labelled diets, and this factor is assumed to lead to an underestimation of the endogenous losses (Leterme et al. 1996). The results obtained with labelled pigs are largely dependent on the identification of an adequate and accessible reference pool reflecting the enrichment of the endogenous proteins secreted in the lumen (Hess et al. 1998b; Leterme et al. 1998).

The aim of the present experiment was to determine to what extent the two ways of labelling introduce errors in the determination of real digestibility. The comparison of the two methods was performed within pigs, first fed on diets containing unlabelled peas and labelled by constant infusion of $\left[1-{ }^{13} \mathrm{C}\right]$ leucine, and second, fed on a meal of the same diet containing ${ }^{15} \mathrm{~N}$-labelled peas. In the current paper we present the ileal endogenous $\mathrm{N}$ and AA flows as well as the real digestibility estimated with those labelled diets. We also compare the leucine value with that obtained with $\left[1-{ }^{13} \mathrm{C}\right]$ leucine-labelled pigs.

\section{Materials and methods}

Animals: surgical preparation

The experiment was conducted under the guidelines of the French Ministry of Agriculture for animal research. Three growing Piétrain $\times$ Large White pigs from the herd of $\mathrm{St}$ Gilles with an average body weight of $35.8 \mathrm{~kg}$ were individually housed in metabolism cages allowing total and separate collection of ileal chyme and urine. The pigs were then prepared with an end-to-end ileo-rectal, antevalvular anastomosis as described by Laplace et al. (1989). At 4 weeks later, catheters were fitted in the portal vein, the jugular vein (silicon catheter, i.d. $0.85 \mathrm{~mm}$, o.d. $1.60 \mathrm{~mm}$ (silastic, Vermed, France) 40 and $180 \mathrm{~mm}$ deep respectively)

\footnotetext{
Abbreviations: AA, amino acids; DMI, dry matter intake.

* This work has been reported in part in Hess et al. (1998a).

$\dagger$ Corresponding author: Dr Bernard Sève, fax +3329928 50 80, email seve@st-gilles.rennes.inra.fr
} 
and the carotid artery (polyvinyl chloride carotid catheter, i.d. $1.02 \mathrm{~mm}$, o.d. $1.50 \mathrm{~mm}$ (Dural Plastic Engineering, Australia) $180 \mathrm{~mm}$ deep).

\section{Infusions and blood sampling}

The infusion of the $\left[1-{ }^{13} \mathrm{C}\right]$ leucine $\left(99 \%{ }^{13} \mathrm{C}\right.$-enrichment; Cambridge Isotope Labs. Inc., Andover, MA, USA) started on the week following the insertion of the catheters. A sterile leucine solution was continuously infused at a level of $8.9 \mathrm{mg}$ leucine $/ \mathrm{kg}$ body weight ${ }^{0.75}$ per $\mathrm{d}$ and at a rate of $2 \mathrm{ml} / \mathrm{h}$ for $24 \mathrm{~d}$ as previously described (Hess et al. 1998b) (Fig. 1). The solution was infused into the jugular vein and carotid artery using a syringe pump (Perfusor, Braun, Germany). The site of infusion was alternated on the day following blood sampling. Blood samples taken from the portal vein were analysed for $\left[{ }^{13} \mathrm{C}\right]$ leucine enrichment since the enrichment of free AA in the plasma of the portal vein better reflects the enrichment of the endogenous secreted AA (Hess et al. 1998b). In total there were eleven blood samples on each animal. The first sample was obtained before starting the infusion in order to determine the basal enrichment of $\left[{ }^{13} \mathrm{C}\right]$ leucine in the pigs. During the infusion, each sample consisted of $20 \mathrm{ml}$ made of four equal portions collected at 08.00 hours (before the morning meal), 10.00, 12.00 and 14.00 hours on days $3,5,8,10,12,15,17,19,22$ and 24. Each blood sample was collected into an ice-cooled tube which contained $50 \mathrm{IU}$ heparin, and was then centrifuged. Plasma was removed and stored at $-20^{\circ}$ until further analysis.

\section{Diet and digesta collection}

Two pea cultivars (Pisum sativum L. cv. Solara and Amino) were grown in 1996 by G. Duc (INRA, Station de Génétique at d'Amélioration des plantes de Dijon, 21034 Dijon cedex, France). In each field, a restricted area (about $40 \mathrm{~m}^{2}$ ) received labelled ammonium nitrate $\left({ }^{15} \mathrm{~N}_{2}, 11.5 \%\right.$, Cambridge Isotope Labs. Inc.). All tested products were ground through a $2.5 \mathrm{~mm}$ mesh screen before mixing. A protein-free diet and two diets containing $150 \mathrm{~g}$ protein $/ \mathrm{kg}$, using pea cultivars each as the only protein source, were formulated (Table 1). Labelled diets were formulated by substitution of labelled for unlabelled pea and $\mathrm{Cr}_{2} \mathrm{O}_{3}(3 \mathrm{~g} / \mathrm{kg})$ was

\begin{tabular}{|c|c|c|c|c|c|c|c|c|}
\hline & 1 & 2 & 3 & & & & & \\
\hline \multicolumn{2}{|l|}{ Period 1} & A 4 & A 5 & A 6 & A 7 & C 8 & C 9 & $\mathrm{~T} 10$ \\
\hline \multirow{2}{*}{\multicolumn{2}{|c|}{$\begin{array}{l}\text { Period } 2 \\
\text { Period } 3\end{array}$}} & A 11 & A 12 & A 13 & A 14 & C 15 & C 16 & T 17 \\
\hline & & A 18 & A 19 & A 20 & A 21 & C 22 & C 23 & T 24 \\
\hline \multirow{2}{*}{\multicolumn{2}{|c|}{ Slaughter }} & 25 & & & & & & \\
\hline & & \multicolumn{3}{|c|}{ Blood sample } & \multicolumn{4}{|c|}{ Blood sample Blood sar } \\
\hline
\end{tabular}

Fig. 1. Design of the experiment. The infusion of $\left[1-{ }^{13} \mathrm{C}\right]$ leucine lasted $24 \mathrm{~d}$. At $3 \mathrm{~d}$ following the start of the infusion, three diets were given according to a Latin-square design. After $4 \mathrm{~d}$ of adaptation $(A)$ to a diet, total digesta collection (C) was carried out for $2 \mathrm{~d}$. On the 7 th $\mathrm{d}$ of each period, a ${ }^{15} \mathrm{~N}$-labelled test diet $(\mathrm{T})$ was given and the digesta was collected every hour for $9 \mathrm{~h}$. Blood samples were taken before and on days $3,5,8,10,12,15,17,19,22$, and 24 of the infusion. substituted for starch. Before feeding the experimental diets, the pigs were fed on a standard grower diet.

The animals were fed at $80 \mathrm{~g} \mathrm{DM} / \mathrm{kg}$ body weight ${ }^{0.75}$ per d at 08.00 and 15.30 hours in two equal portions mixed with water $(1: 2, \mathrm{w} / \mathrm{v})$. At $3 \mathrm{~d}$ after beginning the $\left[1-{ }^{13} \mathrm{C}\right]$ leucine infusion, the experimental diets were offered according to a Latin-square design. After $4 \mathrm{~d}$ of adaptation to an experimental diet (days 4-7, 11-14, 18-22), the ileal digesta that appeared over $48 \mathrm{~h}$ was quantitatively recovered in $500 \mathrm{ml}$ $0.7 \mathrm{M}-\mathrm{H}_{2} \mathrm{SO}_{4}$. Collections of digesta were made immediately after each meal. Urine was collected into $1.9 \mathrm{M}-\mathrm{H}_{2} \mathrm{SO}_{4}$. The pigs received the unlabelled diet except in the morning on days 10,17 , and 24 when they were given the ${ }^{15} \mathrm{~N}$-labelled test diet containing $\mathrm{Cr}_{2} \mathrm{O}_{3}$. Following the distribution of the test diet, the digesta was quantitatively collected in plastic bags for $9 \mathrm{~h}$. A collection was made each hour. Immediately after collection, the bags were stored at $-20^{\circ}$, then freezedried, weighed and stored in a cool place until further analysis. When the pigs were fed on the protein-free diet, the total collection period was $3 \mathrm{~d}$.

\section{Chemical analysis}

Digesta collected for $2 \mathrm{~d}$ was analysed for DM, N and AA contents and $\left[{ }^{13} \mathrm{C}\right]$ leucine enrichment. The hourly digesta collections were analysed for DM, N, $\mathrm{Cr}_{2} \mathrm{O}_{3}$ and total ${ }^{15} \mathrm{~N}$ enrichment. A few hours following the distribution of the labelled diet, a parallel excretion of $\mathrm{Cr}_{2} \mathrm{O}_{3}$ concentration and ${ }^{15} \mathrm{~N}$ enrichment was observed in the ileal digesta as described by Leterme et al. (1996). The first labelled ileal juice immediately displayed a high labelling with both ${ }^{15} \mathrm{~N}$ and $\mathrm{Cr}_{2} \mathrm{O}_{3}$. The first samples not containing any $\mathrm{Cr}_{2} \mathrm{O}_{3}$ were discarded. The four samples following the first with $\mathrm{Cr}_{2} \mathrm{O}_{3}$, until a recovery of $55 \%$ of the $\mathrm{Cr}_{2} \mathrm{O}_{3}$ administered, were pooled per animal and per diet, in order to get a representative mean sample of digesta in which AA content and the ${ }^{15} \mathrm{~N}$ enrichments of total $\mathrm{N}$ and AA were measured.

For deproteinization, plasma samples were mixed with a 0.6 M-TCA solution (Prolabo Normapur, 20.742.293, France) $(1: 2, \mathrm{v} / \mathrm{v})$. TCA-soluble and TCA-precipitable fractions were separated by centrifugation. The TCAprecipitable fractions were washed with another volume of TCA. The two TCA-soluble fractions were pooled. N content was measured with an elemental analyser according to the Dumas method (Leco FP 428 analyser; Leco, St Joseph, MO, USA). For total ${ }^{15} \mathrm{~N}$ analysis, an elemental analyser (C.E. 1500 NA; Carlo Erba, Milano, Italy) interfaced with an isotope ratio mass spectrometer (Optima, Micromass, Cheshire, UK) was used. $\mathrm{Cr}_{2} \mathrm{O}_{3}$ was analysed by colorimetry according to the method of Poncet \& Rayssiguier (1980). The AA contents in the digesta and diets were determined by liquid ion-exchange chromatography (Biochrom 20, Pharmacia, Saclay, France) after a $23 \mathrm{~h}$ hydrolysis in $6 \mathrm{M}-\mathrm{HCl}$. A factor of 1.06 was used to correct the values for serine, valine and isoleucine. For $\mathrm{S}$ amino acids, the acid hydrolysis was preceded by a performic oxidation. Tryptophan was hydrolysed in $1.5 \mathrm{M}-\mathrm{BaOH}$ solution for $20 \mathrm{~h}$, separated by HPLC and detected by fluorimetry (Waters 600E, St Quentin en Yvelines, France). The ${ }^{15} \mathrm{~N}$-labelled AA and $\left[{ }^{13} \mathrm{C}\right]$ leucine enrichment were determined by $\mathrm{GC}$-combustion-isotope-ratio mass 
Table 1. Compositions $(\mathrm{g} / \mathrm{kg}$ ) of the protein-free diet and diets containing different pea cultivars (Solara and Amino) unlabelled, or labelled with ${ }^{15} \mathrm{~N}$

\begin{tabular}{|c|c|c|c|c|c|}
\hline & \multirow[b]{2}{*}{ Protein free } & \multicolumn{2}{|c|}{ Solara } & \multicolumn{2}{|c|}{ Amino } \\
\hline & & Unlabelled* & Labelled $†$ & Unlabelled $\ddagger$ & Labelled§ \\
\hline \multicolumn{6}{|l|}{ Ingredient } \\
\hline Pea & - & 78.37 & - & 86.72 & - \\
\hline Labelled pea & - & - & 78.37 & - & $86 \cdot 72$ \\
\hline Maize starch & $79 \cdot 42$ & $10 \cdot 14$ & 9.84 & $2 \cdot 21$ & 1.91 \\
\hline Wood cellulose & 5 & 0 & 0 & 0 & 0 \\
\hline Maize oil & 3 & $1 \cdot 75$ & 1.75 & 1.61 & 1.61 \\
\hline Sugar & 5 & 3.35 & 3.35 & $3 \cdot 17$ & $3 \cdot 17$ \\
\hline $\mathrm{KCl}$ & 0.27 & 0 & 0 & 0 & 0 \\
\hline $\mathrm{NaCl}$ & 0.84 & 0.84 & 0.84 & 0.84 & 0.84 \\
\hline $\mathrm{Na}_{2} \mathrm{CO}_{3}$ & 1.46 & 1.43 & 1.43 & 1.43 & 1.43 \\
\hline $\mathrm{MgCl}$ & 0.33 & 0 & 0 & 0 & 0 \\
\hline Dicalcium phosphate & 2.03 & 0.76 & 0.76 & 0.62 & 0.62 \\
\hline $\mathrm{CaCO}_{3}$ & 1.57 & 1.91 & 1.91 & 1.95 & 1.95 \\
\hline DL-Methionine & 0 & 0.29 & 0.29 & 0.28 & 0.28 \\
\hline L-Tryptophan & 0 & 0.08 & 0.08 & 0.09 & 0.09 \\
\hline $\mathrm{Cr}_{2} \mathrm{O}_{3}$ & 0 & 0 & 0.3 & 0 & 0.3 \\
\hline Premix\| & 1 & 1 & 1 & 1 & 1 \\
\hline Additional premix $\llbracket$ & 0.08 & 0.08 & 0.08 & 0.08 & 0.08 \\
\hline \multicolumn{6}{|l|}{ Chemical analysis } \\
\hline DM & $89 \cdot 37$ & $89 \cdot 34$ & $88 \cdot 74$ & $89 \cdot 13$ & $89 \cdot 37$ \\
\hline $\mathrm{N}$ & 0.07 & 2.42 & 2.48 & 2.42 & 2.47 \\
\hline $\mathrm{DE}(\mathrm{kJ} / \mathrm{kg})^{* *}$ & 3114 & \multicolumn{2}{|c|}{3218} & \multicolumn{2}{|c|}{3207} \\
\hline $\operatorname{NDF}(\mathrm{g} / \mathrm{kg})$ & $4 \cdot 14$ & \multirow{2}{*}{\multicolumn{2}{|c|}{$\begin{array}{l}7.88 \\
4.70\end{array}$}} & \multirow{2}{*}{\multicolumn{2}{|c|}{$\begin{array}{l}9.03 \\
5.14\end{array}$}} \\
\hline ADF $(\mathrm{g} / \mathrm{kg})$ & $2 \cdot 81$ & & & & \\
\hline Enrichment (APE) & - & 0.0017 & 0.7327 & 0.0010 & 0.8483 \\
\hline TIA (unit/g DM) & - & \multicolumn{2}{|c|}{3496} & \multicolumn{2}{|c|}{4777} \\
\hline
\end{tabular}

$\mathrm{DE}$, digestible energy; NDF, neutral-detergent fibre, ADF, acid-detergent fibre; APE, atoms percent excess; TIA, trypsin inhibitor activity.

${ }^{*}$ Contained (g/kg DM): Arg 14.9, His 5.3, Lys 13.4, Phe 8.7, Leu 12.6, Ileu 8.2, Val 8.8, Met 4.7, Thr 7.4, Trp 3.4, Asp 20.8, Glu 27.6, Ser $9 \cdot 2$, Gly $8 \cdot 0$, Ala $8 \cdot 1$, Cys $3 \cdot 1$, Tyr $5 \cdot 8$, Pro $7 \cdot 2$.

† Contained (g/kg DM): Arg 14.3, His 4.4, Lys 12.7, Phe 8.3, Leu 12.3, lleu 7.8, Val 8.2, Met 4.3, Thr 6.6, Trp 2.1, Asp 18.9, Glu 25.8,

Ser $8 \cdot 5$, Gly $7 \cdot 6$, Ala $7 \cdot 7$, Cys $3 \cdot 0$, Tyr $5 \cdot 6$, Pro $7 \cdot 0$

¥ Contained (g/kg DM): Arg 14.5, His 5.0, Lys 13.4, Phe 9.3, Leu 13.5, lleu 9.3, Val 9.3, Met 4.5, Thr 7.1, Trp 2.7, Asp 20.5, Glu 28.0, Ser $9 \cdot 3$, Gly $8 \cdot 1$, Ala $8 \cdot 2$, Cys $3 \cdot 0$, Tyr $6 \cdot 3$, Pro $8 \cdot 1$.

§ Contained (g/kg DM): Arg 13.8, His 4.8, Lys 13.2, Phe 9.2, Leu 13.1, Ileu 9.0, Val 9.2, Met 4.4, Thr 7.3, Trp 2.5, Asp 20.6, Glu 27.5, Ser $9 \cdot 3$, Gly $8 \cdot 4$, Ala $8 \cdot 6$, Cys $3 \cdot 0$, Tyr 6.2, Pro $7 \cdot 1$

$\|$ Contained (g/kg premix): retinol 1, cholecalciferol 0.2, $\alpha$-tocopherol acetate 4, menadione 0.8 , thiamin 0.2 , riboflavin 0.5 , niacin 1.5 , pyridoxine- $\mathrm{HCl} 0 \cdot 1$, biotin $1 \cdot 0$, pteroylmonoglutamic acid $0 \cdot 1$, cyanocobalamin $0 \cdot 2$, choline 80 , calcium pantothenate $1 \cdot 0, \mathrm{Fe} 7 \cdot 98$, Cu 1.0, Mn 4.34, Zn 10.2, Co 0.01, I 0.02, Se 0.015

\ Contained (mg/kg premix): retinol 44, $\alpha$-tocopherol acetate 50, menadione 24, thiamin 5, riboflavin 5, pyridoxine- $\mathrm{HCl} 4$, biotin (1\%) $8 \cdot 75$, pteroylmonoglutamic acid 1 , cyanocobalamin 25 , ascorbic acid 50 , niacin 25

${ }^{* *}$ As estimated according to Institut National de la Recherche Agronomique (1989).

spectrometry as previously described (Le Floc'h et al. 1997; Hess et al. 1998b).

\section{Calculation}

Two ways of calculation were compared. First, using the labelled meal, the endogenous losses were calculated as the amount of unlabelled $\mathrm{N}$ on the basis of recovered $\mathrm{Cr}_{2} \mathrm{O}_{3}$ in the digesta (equation 3). Second, it was considered that the labelled diet allowed the accurate determination of the real digestibility (equation 6) but not of the endogenous flows. The total endogenous flows were calculated as the difference between the apparently digestible fraction measured with the $2 \mathrm{~d}$ collection data and the truly digestible fraction measured with the test meal collection data (per animal per diet) (equation $3^{\prime}$ ).

When the isotope dilution method was performed with labelled pigs, the endogenous leucine losses were calculated using the following equation (de Lange et al. 1990):

leuendo $=$ [leudigesta $\times($ E13digesta

$$
\text { - E13diet)/(E13blood - E13diet)]/DMI, }
$$

where leuendo is the total endogenous leucine losses in ileal juice in $\mathrm{g} / \mathrm{kg}$ DMI; leudigesta is the total leucine in ileal juice in g; E13diet, E13blood, E13digesta are the ${ }^{13} \mathrm{C}$ enrichment values for leucine in the diet, in the plasma TCA-soluble fraction and the ileal juice respectively, in atom percent excess; DMI is DM intake in $\mathrm{kg}$.

When the isotope dilution method was performed with labelled diets, the endogenous $\mathrm{N}$ and $\mathrm{AA}$ losses were calculated using the following equation (Leterme et al. 1997):

$$
\% \text { Nendo }=100-(100 \times \text { E15digesta/E15diet }),
$$

where $\%$ Nendo is the proportion of endogenous N (AA) in the digesta collected from the test meal; E15digesta and 
E15diet are the ${ }^{15} \mathrm{~N}$ in the digesta and diet respectively, in atom percent excess.

$$
\text { Nendo }=(\% \text { Nendo/100 }) \times \mathrm{Nd} \times \mathrm{Cri} / \mathrm{Crd} \times \mathrm{DMI},
$$

where Nendo is the quantity of endogenous $\mathrm{N}$ or AA in $\mathrm{g} / \mathrm{kg}$ DMI; $\mathrm{Nd}$ is the quantity of $\mathrm{N}$ in the digesta in $\mathrm{g} / \mathrm{kg} \mathrm{DM}$; Cri and $\mathrm{Crd}$ are the quantities of $\mathrm{Cr}_{2} \mathrm{O}_{3}$ in $\mathrm{g} / \mathrm{kg} \mathrm{DM}$ in the diet and in the digesta respectively.

The digestibility coefficients of N (AA) were calculated as follows:

$$
\text { apparent digestibility }=100 \times(1-(\mathrm{Nd} / \mathrm{DMI}) / \mathrm{Ni})
$$

$$
\text { ( } 2 \text { d collection), }
$$

or

$$
\text { apparent digestibility }=100 \times(1-(\mathrm{Nd} \times(\mathrm{Cri} / \mathrm{Crd})) / \mathrm{Ni})
$$

(test meal collection).

True digestibility $=100 \times(1-(\mathrm{Nd} \times \mathrm{DME} / \mathrm{DMI}$

$$
\text { - Nbasendo)/Ni) (2 d collection), (5) }
$$

where Nbasendo is the basal endogenous losses defined as the ileal flow collected from the protein-free diet in $\mathrm{g} / \mathrm{kg}$ DMI, Ni is the quantity of $\mathrm{N}$ ingested per DMI, DME is the DM excreted in $\mathrm{kg}$.

$$
\begin{aligned}
\text { Real digestibility }= & 100 \times(1-(\mathrm{Nd} \times \mathrm{DME} / \mathrm{DMI} \\
& -\mathrm{Nendo}) / \mathrm{Ni})\left({ }^{15} \mathrm{~N}\right. \text {-labelled test meal } \\
& \text { or } \left.\left[{ }^{13} \mathrm{C}\right] \text { leucine-labelled pig }\right) .
\end{aligned}
$$

An alternative calculation of the endogenous flow was made by difference using the total ileal flow obtained with the $2 \mathrm{~d}$ samples and the dietary ileal flow estimated using the real digestibility (RD) coefficient determined with the respective test meal:

$$
\text { Nendo }=\mathrm{Nd} \times \mathrm{DME} / \mathrm{DMI}-\mathrm{Ni} \times(1-(\mathrm{RD} / 100)) .
$$

Values are presented as means with their standard errors. ANOVA was carried out to assess the differences between diets using the general linear models procedure of SAS (1989; Statistical Analysis Systems Inc., Cary, NC, USA). A Student follow up $t$ test was used for comparisons of means and differences were declared significant at $P<0 \cdot 1$.

\section{Results}

All the animals were in good health and consumed their feed allowance throughout the experiment.

The $\mathrm{N}$ and AA apparent and true digestibilities of the two tested peas, determined with the $2 \mathrm{~d}$ collection data, are presented in Table 2. The apparent digestibilities of Amino were lower than those of Solara. Due to the small number of data, there were significant differences only for lysine, arginine, histidine and methionine. The same results were obtained with the test meal collection data using the $\mathrm{Cr}_{2} \mathrm{O}_{3}$ marker but the differences were not significant due to a higher standard error (results not shown).

The endogenous flows of $\mathrm{N}$ and some AA expressed in $\mathrm{g} / \mathrm{kg}$ DMI are presented in Table 3. The SEM for leucine, isoleucine, valine, threonine and glycine were similar with the two methods of calculation (test meal collection and $2 \mathrm{~d}$ samples). In contrast, the SEM for lysine, phenylalanine, alanine and proline were higher with the $2 \mathrm{~d}$ collection than

Table 2. Apparent and true digestibilities of the nitrogen and amino acids in two pea cultivars (Solara and Amino) measured in pigs over two collection days*

(Mean values with their pooled standard errors for six observations)

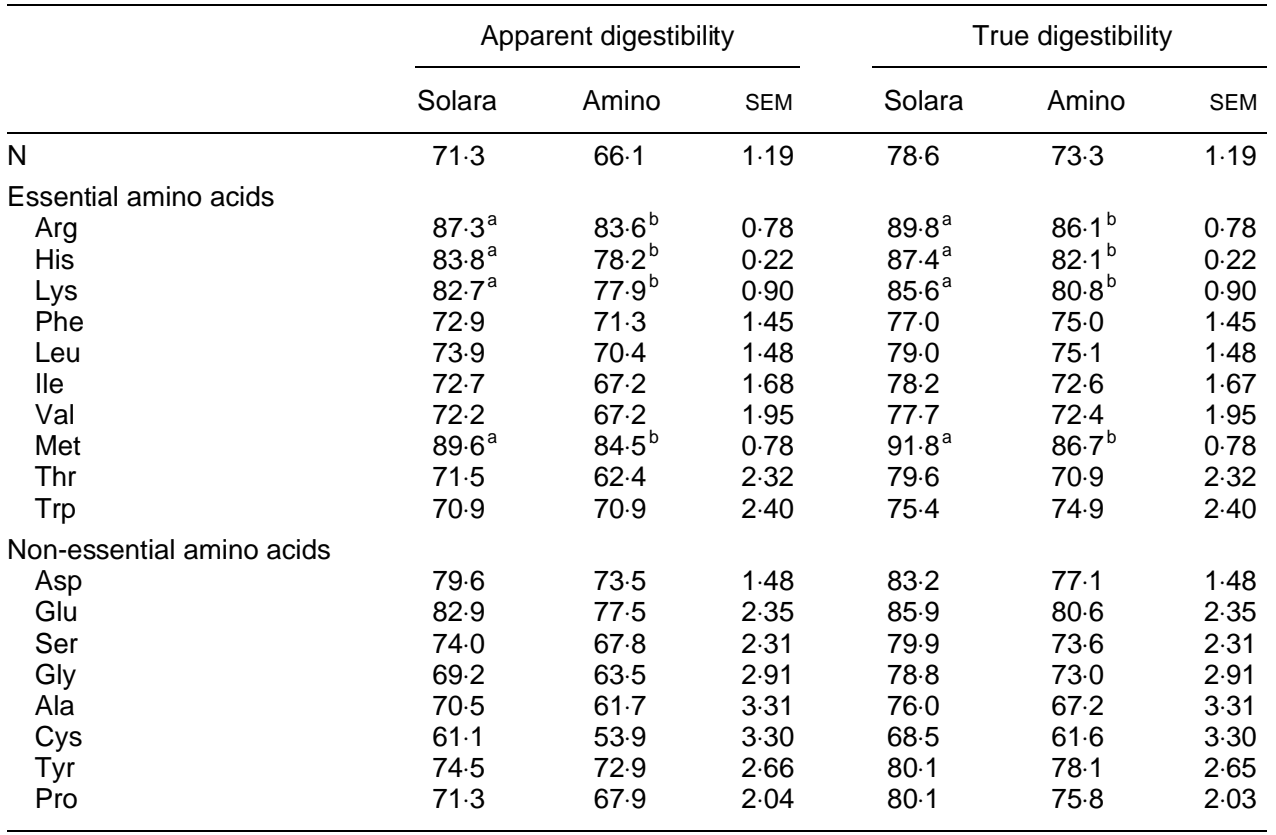

a,b Mean values within a row not sharing a common superscript letter were significantly different, $P<0.1$.

* For details of diets and procedures, see Table 1 and pp. 124-126. 
Table 3. Endogenous nitrogen and amino acid flows ( $\mathrm{g} / \mathrm{kg} \mathrm{DM}$ intake) at the end of the ileum, determined by two different methods, in pigs fed on a protein-free (PF) diet and two diets containing different pea cultivars (Solara and Amino)*

(Mean values with their pooled standard errors for nine observations)

\begin{tabular}{|c|c|c|c|c|c|c|c|c|c|}
\hline \multirow{2}{*}{$\begin{array}{l}\text { Method... } \\
\text { Diet... }\end{array}$} & \multicolumn{4}{|c|}{ Test-meal collection } & \multicolumn{5}{|c|}{$2 \mathrm{~d}$ collection } \\
\hline & PF & Solara & Amino & SEM & PF & PF† & Solara & Amino & SEM \\
\hline \multicolumn{10}{|c|}{ Endogenous flow (g/kg DM intake) } \\
\hline $\mathrm{N}$ & 1.98 & 2.38 & 3.43 & 0.52 & $1.98^{a}$ & - & $2 \cdot 63^{\mathrm{ab}}$ & $2.90^{\mathrm{b}}$ & $0 \cdot 18$ \\
\hline Lys & $0.39^{a}$ & $0.43^{\mathrm{ab}}$ & $0.72^{b}$ & 0.07 & 0.39 & - & 0.38 & 0.92 & 0.22 \\
\hline Phe & $0.35^{a}$ & $0.53^{b}$ & $0.71^{\mathrm{c}}$ & 0.04 & $0.35^{a}$ & - & $0.57^{\mathrm{ab}}$ & $0.88^{b}$ & 0.10 \\
\hline Leu $\left({ }^{15} \mathrm{~N}\right)$ & $0.63^{\mathrm{a}}$ & $0.97^{\mathrm{b}}$ & $0.58^{a}$ & 0.06 & $0.63^{a}$ & - & $0 \cdot 89^{a b}$ & $1.02^{b}$ & 0.07 \\
\hline Leu $\left({ }^{13} \mathrm{C}\right) \dagger$ & - & - & - & - & $0.63^{a}$ & $0.57^{a}$ & $1.59^{b}$ & $1.61^{b}$ & 0.20 \\
\hline Ile & 0.44 & 0.79 & 0.62 & 0.08 & $0.44^{a}$ & - & $0 \cdot 73^{\mathrm{ab}}$ & $0.86^{\mathrm{b}}$ & 0.08 \\
\hline Val & $0.49^{a}$ & $0.74^{\mathrm{ab}}$ & $0.87^{b}$ & 0.07 & $0.49^{a}$ & - & $0.52^{\mathrm{ab}}$ & $1.22^{\mathrm{b}}$ & 0.06 \\
\hline Thr & $0.60^{\mathrm{a}}$ & $0.87^{b}$ & $0.92^{b}$ & 0.04 & $0.60^{\mathrm{a}}$ & - & $0 \cdot 72^{b}$ & $1.29^{\mathrm{C}}$ & 0.02 \\
\hline Gly & $0.77^{\mathrm{a}}$ & $1.01^{\mathrm{b}}$ & $0.93^{\mathrm{b}}$ & 0.04 & $0.77^{\mathrm{a}}$ & - & $0.79^{a}$ & $1.36^{\mathrm{b}}$ & 0.05 \\
\hline Ala & $0.45^{\mathrm{a}}$ & $0.70^{\mathrm{b}}$ & $0.65^{b}$ & 0.04 & $0.44^{a}$ & - & $0.84^{a}$ & $1.47^{\mathrm{b}}$ & 0.15 \\
\hline Pro & 0.63 & 0.65 & 0.64 & 0.03 & $0.63^{a}$ & - & 0.62 & 0.79 & 0.11 \\
\hline
\end{tabular}

${ }_{a, b, c}$ Mean values within a row not sharing a common superscript letter were significantly different, $P<0.1$.

${ }^{*}$ For details of diets and procedures, see Table 1 and pp. 124-126.

†Endogenous leucine estimated by the isotope dilution method using the portal free $\left[{ }^{13} \mathrm{C}\right]$ leucine enrichment as reference in proteindeprived pigs ( $n$ 12).

with the test meal collection. Using the test meal sample, due to high variability, total ileal endogenous losses of $\mathrm{N}$ recovered from the protein diets did not differ from the basal losses determined with the protein-free diet. For Solara, the estimated endogenous losses of AA differed from the basal losses except for lysine, isoleucine, valine and proline. The Amino diet induced higher than basal AA endogenous flows for lysine, phenylalanine, threonine, glycine and alanine. The endogenous flows differed significantly between Solara and Amino only for phenylalanine and leucine. Using the second method of calculation (equation $3^{\prime}$ ) the endogenous losses associated with the Amino cultivar were significantly higher than the basal losses for $\mathrm{N}$ and all the AA except lysine (due to a high standard error). The differences between Solara and basal losses reached statistical significance only for threonine. The endogenous losses were significantly higher with Amino than with Solara for threonine, glycine, alanine and proline. For $\mathrm{N}$ and all the AA except alanine, there was no significant effect of the method of calculation to determine the endogenous flows and the interaction between the method of calculation and diet was never significant (results not shown).

For the determination of the endogenous losses of leucine, the two methods of calculation with labelled feedstuffs, using the test meal and the $2 \mathrm{~d}$ collection data, are compared with the results obtained with labelled pigs on the pooled data of each cultivar of pea (Table 4). The ileal endogenous loss and real digestibility of leucine determined with the labelled foodstuff were significantly lower than those determined with the labelled pig. Calculation of the endogenous losses by the $2 \mathrm{~d}$ samples method led to an intermediate value, although this value was not significantly higher than the test meal value and was significantly lower than that obtained from the labelled pig determination.

The real digestibility coefficients are presented in Table 5 . The real digestibilities of $\mathrm{N}$ and AA did not differ between the two cultivars. This lack of difference was due to the small number of data.

\section{Discussion}

The aim of the present experiment was to compare the isotope dilution method performed by labelling the pig with that performed by labelling diets. By labelling the pig, the $\left[{ }^{13} \mathrm{C}\right]$ leucine enrichment was determined in the portal vein in accordance with previous data obtained with $\left[{ }^{15} \mathrm{~N}\right]$ leucine infusion (Hess et al. 1998b). Leterme et al. (1998) compared total ${ }^{15} \mathrm{~N}$ with the $\left[{ }^{13} \mathrm{C}\right]$ leucine isotope

Table 4. Endogenous ileal loss and real digestibility (RD) of leucine measured by two different isotope dilution methods: labelling the diet with ${ }^{15} \mathrm{~N}$ (two different methods of calculation) and labelling the pig with ${ }^{13} \mathrm{C}^{\star}$

(Mean values for eighteen (endogenous losses) or twelve (RD) observations with their pooled standard errors)

\begin{tabular}{|c|c|c|c|c|c|c|c|}
\hline \multirow{2}{*}{$\begin{array}{l}\text { Labelling method... } \\
\text { Calculation method... }\end{array}$} & \multicolumn{2}{|c|}{${ }^{15} \mathrm{~N}$ diet } & \multirow[t]{2}{*}{${ }^{13} \mathrm{C}$ pig } & \multirow[b]{2}{*}{ SEM } & \multicolumn{3}{|c|}{$\begin{array}{l}\text { Statistical significance } \\
\text { of effect of: }(P=)\end{array}$} \\
\hline & Test meal & $2 d$ & & & C & $D$ & $C \times D$ \\
\hline $\begin{array}{l}\text { Endogenous loss } \\
\text { RD }\end{array}$ & $\begin{array}{l}0.77^{\mathrm{a}} \\
79.5^{\mathrm{a}}\end{array}$ & $\begin{array}{l}0.95^{\mathrm{a}} \\
-\end{array}$ & $\begin{array}{l}1.61^{\mathrm{b}} \\
84.5^{\mathrm{b}}\end{array}$ & $\begin{array}{l}0.15 \\
0.72\end{array}$ & $\begin{array}{l}0.01 \\
0.01\end{array}$ & $\begin{array}{l}0.52 \\
0.32\end{array}$ & $\begin{array}{l}0.50 \\
0.59\end{array}$ \\
\hline
\end{tabular}

C, calculation method; D, diet.

${ }_{\mathrm{a}, \mathrm{b}}$ Mean values within a row not sharing a common superscript letter were significantly different, $P<0.05$.

${ }^{*}$ For details of diets and procedures, see Table 1 and pp. 124-126. 
Table 5. Real digestibilities of nitrogen and amino acids in two different pea cultivars (Solara and Amino) determined with ${ }^{15} \mathrm{~N}$ labelled diet and ${ }^{13} \mathrm{C}$-labelled pig*

(Mean values with their pooled standard errors for six observations)

\begin{tabular}{lccc}
\hline & Solara & Amino & SEM \\
\hline $\mathrm{N}$ & 81 & 77 & $1 \cdot 3$ \\
Lys & 86 & 85 & $2 \cdot 0$ \\
Phe & 80 & 81 & $4 \cdot 1$ \\
Leu $\left({ }^{15} \mathrm{~N}\right) \dagger$ & 81 & 78 & $2 \cdot 7$ \\
Leu $\left({ }^{13} \mathrm{C}\right) \ddagger$ & 87 & 82 & $1 \cdot 7$ \\
Ile & 82 & 78 & $2 \cdot 7$ \\
Val & 78 & 80 & $2 \cdot 7$ \\
Thr & 81 & 81 & $2 \cdot 9$ \\
Gly & 79 & 80 & $3 \cdot 7$ \\
Ala & 82 & 80 & $2 \cdot 6$ \\
Pro & 80 & 78 & $3 \cdot 3$ \\
\hline
\end{tabular}

${ }^{*}$ For details of procedures, see pp. 124-126.

† Leucine real digestibility calculated with the isotopic dilution method using labelled diet.

$\ddagger$ Leucine real digestibility calculated with the isotopic dilution method taking the portal free $\left[{ }^{13} \mathrm{C}\right]$ leucine enrichment as reference.

dilution method by labelling the animals. They concluded that $\left[{ }^{13} \mathrm{C}\right]$ leucine did not allow the determination of the total $\mathrm{N}$ endogenous losses. However, it has been shown that total $\mathrm{N}$ dilution method data cannot be extrapolated to the individual AA (de Lange et al. 1990, 1992; Lien et al. 1997; Hess et al. 1998b). Moreover, Leterme et al. (1998) used systemic blood as the reference pool, and this may have led to an underestimation of the ileal flow of the endogenous proteins (Hess et al. 1998b). Furthermore, using the leucine isotope dilution method, these authors showed that the proportion of endogenous leucine in the ileal digesta was the same with either $\left[{ }^{15} \mathrm{~N}\right]$ leucine-labelled pigs or $\left[{ }^{13} \mathrm{C}\right]$ leucine-labelled pigs. Therefore, the AA dilution method can be performed either with $\left[{ }^{15} \mathrm{~N}\right]$ or $\left[{ }^{13} \mathrm{C}\right]$ leucine. In the present experiment, the endogenous loss of leucine calculated with the AA dilution method did not differ significantly from that measured with the protein-free diet. The present data support the previous conclusion that the AA isotope dilution method is appropriate when performed by pig labelling with the portal enrichment as reference pool (Hess et al. 1998b). However, a protein-free diet does not prevent unlabelled AA diluting the enrichment of the free plasma pool. The question of whether or not this conclusion may be applied to protein-containing diets may be raised again. The portal vein enrichment is very sensitive to the level of dietary AA (Lobley et al. 1996) and the passage from the fasted to the fed state induces a more pronounced decrease in the enrichment of the tracers in the portal vein than in the artery ( $\mathrm{Yu}$ et al. 1990). The representative precursor pool of the endogenous protein labelling depends on the relative contribution of dietary AA to the precursor pool for secretory protein synthesis. The contribution of lumen protein to enterocyte protein synthesis was clearly demonstrated (Alpers, 1972). If this contribution is less than proportional to the flow, using the enrichment of the portal plasma pool as reference may induce an underestimation of the true enrichment and, accordingly, an overestimation of the endogenous protein losses. This risk is difficult to assess and further work would be needed to evaluate it more precisely.
On the other hand, the results obtained with the labelled diet are impaired by the fast recycling of dietary AA in the secretory tissues and in secretions which leads to underestimation of the endogenous flows of AA and, therefore, leads to an underestimation of the real digestibility according to Leterme et al. (1996). Their data showed that the enrichment of leucine in mucin increased slowly with time. As a consequence, we decided not to include in the analysed mean pool digesta obtained later than $4 \mathrm{~h}$ after the first appearance of ${ }^{15} \mathrm{~N}$, and to limit the recovery of digesta to $55 \%$ of ingested $\mathrm{Cr}_{2} \mathrm{O}_{3}$ in order to calculate a reliable value for real digestibility from $\mathrm{Cr}_{2} \mathrm{O}_{3}$ and ${ }^{15} \mathrm{~N}$ contents. Even under these conditions, the endogenous flow of leucine was calculated to be significantly lower than the endogenous flow determined with the $\left[{ }^{13} \mathrm{C}\right]$ leucine-labelled pig, suggesting that recycling did occur. Another cause for the underestimation of endogenous losses with reduced time of collection may be that secretion of endogenous proteins is a process that continues throughout the day (Corring \& Saucier, 1972; Hee et al. 1988), so that the ileal endogenous flows may be delayed compared with the ileal exogenous flows. Zebrowska et al. (1982) and Darcy-Vrillon et al. (1991) showed post-prandial variations in the relative contributions of endogenous and exogenous materials at the end of the ileum. The most important contributions to the endogenous flows were fractions collected during the first $4 \mathrm{~h}$ and after the 10th $\mathrm{h}$ following the distribution of a protein meal (Darcy-Vrillon \& Laplace, 1983), which were discarded in the current experiment. This means that the restricted collection period, as achieved after the test meal, allows the determination of the exogenous ${ }^{15} \mathrm{~N}$ labelled indigestible fraction, and consequently the real digestibility, but is likely to underestimate the total ileal flows, and consequently the endogenous flows. Therefore, the second method of estimating the endogenous flows by difference between the apparently indigestible flows measured during the $2 \mathrm{~d}$ collection periods and the truly indigestible flows determined during the test meal $8 \mathrm{~h}$ collection period (equation $3^{\prime}$ ), should give a higher and more reliable value than the first method using only the test meal data (equation 3). However, this reassessment did not give significantly higher endogenous losses except for alanine. In fact, the leucine endogenous loss calculated with this alternative method remained largely lower than when estimated by labelling the pig. On the other hand, the endogenous losses of AA estimated with the $2 \mathrm{~d}$ collection method were consistently higher with Amino than with Solara and the data from the test meal collection did not lead to such a clear conclusion. This result suggests that the delay of the endogenous protein flows differed between the two dietary protein sources. Therefore the advantage of collecting digesta for only a few hours after a test meal in reducing the effect of recycling may be reduced by the delay of the endogenous protein flow.

Regarding the usual digestibility data, the correction for basal endogenous losses leads to the calculation of true digestibility (equation 6). Compared with the apparent digestibility values, the true digestibility values did not demonstrate the differences between the two cultivars. Because dietary protein contents were similar, the correction factor of the apparent coefficient was the same for both 
protein sources. For the Solara cultivar, the present apparent digestibility results for $\mathrm{N}$ were lower than those reported by Jondreville et al. (1992), whereas the digestibility of lysine was in accordance with those results (Jondreville et al. 1992; Canibe \& Eggum, 1997). The present results are in agreement with literature data showing large variations of apparent digestibility among different cultivars (Huisman et al. 1992; Jondreville et al. 1992; Fan \& Sauer, 1994). According to some authors, these differences are due to differences in endogenous losses, while pea protein is highly digestible (Bender \& Mohammadiha, 1981; Huisman et al. 1992). The present results show that there were significant differences in the endogenous losses of some AA but not in real digestibility between the two cultivars and they would confirm this point of view. However, previous data (Hess et al. 1998a) have shown that values for real digestibility of $\mathrm{N}$ may also differ between other spring pea cultivars. These results have shown that real digestibility and endogenous losses are independent of each other. Moreover, the present data confirm the poor precision of the isotope dilution method when applied to total $\mathrm{N}$ and that the $\left[{ }^{15} \mathrm{~N}\right]$ or $\left[{ }^{13} \mathrm{C}\right]$ amino acid dilution method is to be preferred in order to determine precisely the endogenous ileal flow of an individual AA.

The present results show that in comparison with the results obtained with labelling of pigs through infusion of labelled AA, the determination of the total endogenous losses with labelled feedstuffs leads to an underestimation, presumably due to the fast recycling of dietary AA in the endogenous secretions. However, the degree of this underestimation may not be clearly assessed due to some question regarding the reference pool used when labelling pigs. The results also suggest that a delay between exogenous and endogenous flows at the end of the ileum may depend on the dietary protein source. However, one of the main problems of the method using the labelled pig is that there is no direct measurement of the endogenous flow of each AA in contrast with the use of labelled protein. Therefore, the use of the latter technique remains of great interest to estimate the endogenous flows and the real digestibility provided that the underestimation is still constant among different protein sources.

\section{Acknowledgements}

We acknowledge the participation of Céline Jau (Ralston Purina France) for amino acid analyses, Yves Lebreton for surgical operations and Francis Le Gouevec for animal care. This work was supported in part by INRA within the ALIMAN incentive action, protein-rich feed programme, managed by Gérard Duc (INRA, Station de Génétique et d'Amélioration des plantes, Dijon, France).

\section{References}

Alpers DH (1972) Protein synthesis in intestinal mucosa: the effect of route of administration of precursor amino acids. Journal of Clinical Investigation 51, 167-173.

Bender AE \& Mohammadiha H (1981) Low digestibility of legume nitrogen. Proceedings of the Nutrition Society 40, 66A.

Canibe N \& Eggum BO (1997) Digestibility of dried and toasted peas in pigs. 2. Ileal and total tract digestibilities of amino acids, protein and other nutrients. Animal Feed Science and Technology 64, 293-310.

Corring T \& Saucier R (1972) Sécrétion pancréatique sur porc fistulé. Adaptation à la teneur en protéine du régime (Pancreatic secretion of the fistulated pig. Adaptation to protein content in the diet). Annales de Biologie Animale Biochemie Biophysique 12, 233-241.

Darcy-Vrillon B \& Laplace JP (1983) Digestion des proteines dans l'intestin grêle chez le porc. 2. Composition en acides aminés des digesta: influence de la source de protéines d'un régime à base d'amidon de maïs purifié et variations postprandriales (Protein digestion in the small intestine of the pig. 2. Amino acid composition of digesta: influence of the dietary protein source of a purified maize starch diet and postprandial variations). Annales de Zootechnie 32, 315-340.

Darcy-Vrillon B, Souffrant WB, Laplace JP, Rérat A, Corring T, Vaugelade P, Gebhardt G \& Köhler R (1991) Exogenous and endogenous contributions to nitrogen fluxes in the digestive tract of pigs fed a casein diet. II. Ileal and faecal digestibilities and absorption of amino acids. Reproduction Nutrition Développement 31, 561-573.

de Lange CFM, Sauer WC, Souffrant W \& Lien KA (1992) ${ }^{15} \mathrm{~N}$ leucine and ${ }^{15} \mathrm{~N}$-isoleucine isotope dilution techniques versus the ${ }^{15} \mathrm{~N}$-isotope dilution technique for determining the recovery of endogenous protein and amino acids in digesta collected from the distal ileum in pigs. Journal of Animal Science 70, 18481856.

de Lange CFM, Souffrant W \& Sauer WC (1990) Real ileal protein and amino acid digestibilities in feedstuffs for growing pigs as determined with the ${ }^{15} \mathrm{~N}$-isotope dilution technique. Journal of Animal Science 68, 409-418.

Fan MZ \& Sauer WC (1994) Amino acids and energy digestibility in peas (Pisum sativum) from white-flowered spring cultivars for growing pigs. Journal of the Science of Food and Agriculture 64, 249-256.

Hee LH, Sauer WC \& Mosenthin R (1988) The measurement of pancreatic secretions in the pig with the pouch technique. Journal of Animal Physiology and Animal Nutrition 60, 241248.

Hess V, Thibault JN, Duc G, Melcion JP, Van Eys J \& Sève B (1998a) Influence de la variété et du microbroyage sur la digestibilité iléale de l'azote et des acides aminés de pois. Digestibilité réelle de l'azote et pertes endogènes spécifiques (Influence of variety and micro-grinding on pea nitrogen and amino acids ileal digestibility. Real nitrogen digestibility and specific endogenous losses). Journée de la Recherche Porcine en France 30, 223-229.

Hess V, Thibault JN \& Sève B (1998b) The ${ }^{15} \mathrm{~N}$ amino acid dilution method allows the determination of the real digestibility and the ileal endogenous losses of the respective amino acid in pigs. Journal of Nutrition 128, 1969-1977.

Huisman J, Heinz TH, van der Poel AFB, van Leeuwen P, Souffrant WB \& Verstegen MWA (1992) True protein digestibility and amounts of endogenous protein measured with the ${ }^{15} \mathrm{~N}$-dilution technique in piglets fed on peas (Pisum sativum) and common beans (Phaseolus vulgaris). British Journal of Nutrition 68, 101-110.

Institut National de la Recherche Agronomique (1989) L'alimentation des Animaux Monogastriques: Porc, Lapin, Vollailles (The Nutrition of Single Stomach Animals: Pig, Rabbit, Fowl), 2nd ed. Paris: INRA.

Jondreville C, Grosjean F, Buron G, Peyronnet C \& Beneytout JL (1992) Comparison of four pea varieties in pig feeding through digestibility on growth performance results. Journal of Animal Physiology and Animal Nutrition 68, 113-122.

Laplace JP, Darcy-Vrillon B, Perez JM, Henry Y, Giger S \& Sauvant D (1989) Associative effects between two fiber sources 
on ileal and overall digestibilities of amino acids, energy and cell-wall components in growing pigs. British Journal of Nutrition 61, 75-87.

Le Floc'h N, Thibault JN \& Sève B (1997) Tissue localization of threonine oxidation in pigs. British Journal of Nutrition 77, 593-603.

Leterme P, Sève B \& Théwis A (1998) The current ${ }^{15} \mathrm{~N}$-leucine infusion technique is not suitable for quantitative measurements of ileal endogenous amino acid flows in pigs. Journal of Nutrition 128, 1961-1968.

Leterme P, Théwis A, Francois E, van Leeuwen P, Wathelet B \& Huisman J (1996) The use of ${ }^{15} \mathrm{~N}$-labeled dietary proteins for determining true ileal digestibilities is limited by their rapid recycling in the endogenous secretions of pigs. Journal of Nutrition 126, 2188-2198.

Lien KA, Sauer WC, Mosenthin R, Souffrant W \& Dugan MER (1997) Evaluation of the ${ }^{15} \mathrm{~N}$-isotope dilution technique for determining the recovery of endogenous protein in ileal digestion of pigs: effect of dilution in the precursor pool for endogenous nitrogen secretion. Journal of Animal Science 75, 148 158.

Lobley GE, Connell A, Revell DK, Bequette BJ, Brown DS \&
Calder AG (1996) Splanchnic-bed transfers of amino acids in sheep blood and plasma, as monitored through use of a multiple $\mathrm{U}-{ }^{13} \mathrm{C}$-labelled amino acid mixture. British Journal of Nutrition 75, 217-235.

Poncet C \& Rayssiguier Y (1980) Effect of lactose supplement on digestion of lucerne hay by sheep. I. Sites of organic matter and nitrogen digestion. Journal of Animal Science 51, $180-185$.

Souffrant WB, Köhler R \& Gebhart G (1981) Untersuchungen zur Bestimmung der endogenen N-Sekretion im Dünndarm bei Schweinen (Investigation for the purpose of determining the endogenous $\mathrm{N}$-secretion in the small intestines of pigs). Archiv für Tierernährung 31, 35-43.

Yu YM, Wagner DA, Tredget EE, Walaszwesky JA, Burke JF \& Young VR (1990) Quantitative role of splanchnic region in leucine metabolism: $\mathrm{L}-\left[1-{ }^{13} \mathrm{C},{ }^{15} \mathrm{~N}\right]$ leucine and substrate balance studies. American Journal of Physiology 259, E36E51.

Zebrowska T, Simon O, Münchmeyer R, Wolf E, Bergner H \& Zebrowska H (1982) Flow of endogenous and exogenous amino acids along the gut of pigs. Archiv für Tierernährung 32, 431444. 